\title{
The influence of condition on the metabolic profile of Czech Fleckvieh cows in the perinatal period
}

\author{
Robert Kupczyński, Maciej Adamski', Daniel Falta², Gustav Chládek² and Wojciech \\ Kruszyński
}

'Department of Environment Hygiene and Animal Welfare, Institute of Animal Breeding, Wroclaw University of Environmental and Life Sciences, Wrocław, Poland, ${ }^{2}$ Department of Animal Breeding, Mendel University of Agriculture and Forestry, Brno, Czech Republic, ${ }^{3}$ Department of Genetics and Animal Breeding, Wroclaw University of Environmental and Life Sciences, Wrocław, Poland

\begin{abstract}
The objective of the study was to determine the influence of Czech Fleckvieh cow's condition before parturition on chosen blood biochemical indices in perinatal period and at the beginning of lactation. The study was conducted on 38 multiparous cows 3-14 days prepartum. The cows were selected with respect to body condition score (BCS): $B C S>4$ points (group I, $\mathrm{n}=18$ ) and $\mathrm{BCS}<4$ points (group $\mathrm{II}, \mathrm{n}=20$ ). Blood was collected at 3-14 and 1-2 days prepartum and 1-2, 21 days postpartum and analyzed for lipid-carbohydrate, protein parameters and enzymatic activity. Cow's condition, milk yield and composition were also estimated. Changes in Czech Fleckvieh cow's condition in a transition period do not have any clear influence on milk yield and composition. An excessive BCS before calving leads to its higher decrease at the beginning of lactation and may indirectly point to a higher energy deficiency in the first period of lactation. It is confirmed by glucose concentration in blood serum decrease $(P<0.01)$ in 3 rd week of lactation when compared to cows with a proper condition before calving ( 3.39 vs. $2.45 \mathrm{mmol} / \mathrm{l})$. Overnormative condition before calving also negatively influences the content of triacylglycerols, alkaline phosphatase and total bilirubin in blood serum in the first days postpartum. TAG transport from liver to blood is impaired at the beginning of lactation in cows with high condition prepartum. The study demonstrated that in Czech Fleckvieh dairy type cows intensified lipolysis and ketogenesis in perinatal period do not take place pointing to high adaptation possibilities of their metabolism.
\end{abstract}

Keywords: Czech Fleckvieh, body condition score, transition period, metabolic profile

\section{Zusammenfassung}

\section{Der Einfluss der Kondition auf das perinatale Stoffwechselprofil Tschechischer Fleckvieh Kühe}

Das Ziel der Untersuchung war es, den Einfluss der vorgeburtlichen Verfassung Tschechischer Fleckvieh Kühe auf die perinatale Phase und den Beginn der Laktation anhand ausgewählter biochemischer Blutparameter zu ermitteln. Dazu wurden 38 multipare Kühe 3 bis 14 Tage prepartum ausgewählt und anhand einer Körperkonditionsbeurteilung (BCS) in zwei Gruppen aufgeteilt: BCS $>4$ Punkte (Gruppe I, $n=18$ ) und $B C S<4$ Punkte (Gruppe II, $n=20$ ). 
Die Blutproben, die vor und nach der Geburt entnommen wurden, wurden hinsichtlich Lipid-Kohlenhydraten, Proteinparametern und Enzymaktivität analysiert. Erfasst wurden auch Kondition, Milchleistung und -zusammensetzung. Änderungen der Kondition bei Tschechischen Fleckvieh Kühen während einer Übergangsphase haben noch keinen deutlichen Einfluss auf die Milchleistung und -zusammensetzung. Ein zu hoher BCS-Wert vor der Geburt führt zu einer stärkeren Veringerung am Beginn der Laktation und kann indirekt zu einem höheren Energiedefizit in der ersten Laktationsphase führen. Ebenfalls negativ beeinflusst wird die Konzentration von Triglyceriden, alkalischer Phosphatase und Gesamtbilirubin im Blutserum in den ersten Tagen nach der Geburt. Auch der TAG-Transport von der Leber zum Blut wird beeinträchtigt. Die Studie zeigte, dass bei Milchkühen der Rasse Tschechisches Fleckvieh vor der Geburt keine verstärkte Lipolyse und Ketogenese stattfindet, was auf hohe Anpassungsmöglichkeiten ihres Stoffwechsels hindeutet.

Schlüsselwörter: Tschechisches Fleckvieh, Körperkonditionsbewertung, Übergangszeit, Stoffwechselprofil

\section{Introduction}

Dairy cows are more susceptible to various diseases in the postpartum period when compared to other production periods, due to the negative energy balance, weakened appetite and increasing yield. That is a period particularly favourable for metabolic disorders (RajalaSchultz et al. 1999). Difficult parturition and problems with fertilisation are more probable to occur in excessively fat cows (Roche et al. 2007). Milk performance in a subsequent lactation depends usually on the proper body condition score (BCS) of cows in the last 100 days of the current lactation (Rodenburg 1992).

The diagnosis of metabolic disorders in herds of cows is based on a whole set of diagnostic examinations, where the determination of biochemical blood indices is an important element (Oetzel 2004, Mordak \& Nicpoń 2006). Preventive-diagnostics programmes also include laboratory analyses of milk, urine, rumen content, and of feed doses (Studer 1998). They aim to eliminate the risk for animal health just before the occurrence of clinical symptoms of disease, reproduction disorders and a decrease in milk yield. Periodical diagnostic monitoring of the herd is of a great significance in the prevention of metabolic disorders and allows additional economic indices in dairy cows breeding to be obtained (Quiroz-Rocha et al. 2009).

In the assessment of the results of laboratory blood analyses, the reference value characteristics for the given cattle population (breed, direction and scale of production) should be taken into consideration. Physiological standards are usually contained within a wide range of values, and as a result, comparisons to them are of a lower diagnostic value, especially in the case of disorders of a subclinical character. The determination of particular biochemical parameters of blood in clinically healthy cows of a given breed with respect to physiological state, performance direction and feeding may provide important information when interpreting results in animals exhibiting pathological symptoms. The assessment of particular biochemical parameters in blood of cows of the Czech Fleckvieh breed of dairy type is justified due to the large abundance of breeding in numerous 
countries. The study concerning only an assessment of lipid profile can be found in the literature (Borucka-Jastrzębska et al. 2007). Also, studies on the Montbeliard breed have been conducted (Ferlay et al. 2006).

The aim of the study was to determine the influence of the condition of Czech Fleckvieh cows (dairy type) before the parturition on chosen biochemical indices of blood in the perinatal period and at the beginning of lactation. The study also aimed at an assessment of an excessive condition of cows in the terminal dry-off period on the level of analysed parameters in blood.

\section{Material and methods}

\section{Animals}

The study was conducted on a Czech Fleckvieh cow farm owned by Proagro Radešínská Svratka (Czech Republic). The herd was free from infectious and invasive diseases. The number of cows in the herd was 330 individuals with an average yield of $6990 \mathrm{~kg}$ of milk, $3.8 \%$ fat and $3.49 \%$ protein. Animals in the perinatal period were kept in a nursery on a deep litter in collective pens (about 15 individuals in each). In the 7th day after parturition, they were moved to a loose barn.

Table 1

Ingredients and chemical composition of TMR

\begin{tabular}{lc}
\hline & \% of DM \\
\hline Ingredients & \\
Maize silage & 50.5 \\
Brewers grains & 23.60 \\
Grass silage & 17.70 \\
Lucerne silage & 17.70 \\
Concentrate & 8.85 \\
Soybean meal & 7.96 \\
Crushed grains (maize and barley) & 7.37 \\
Molasses & 5.90 \\
Rapeseed meal & 4.42 \\
Hay & 5.90 \\
Mineral supplements* & 0.59 \\
Chemical composition & \\
Dry matter & 44.01 \\
Crude fibre & 16.35 \\
Total protein & 18.65 \\
NEL, MJ/ kg & 6.42 \\
Ca & 0.86 \\
P & 0.42 \\
Mg & 0.29 \\
Ka & 0.39 \\
\hline
\end{tabular}

DM: dry matter, NEL: net energy content for lactation, * Mineral supplements - content per kg: Ca $160.7 \mathrm{~g}, \mathrm{P} 48 \mathrm{~g}, \mathrm{Na}$ 65 g, Mg 90 g, Mn 3200 mg, Zn 2600 mg, Cu 300 mg, 100 mg, Se 30 mg, Co 15 mg 
Feeding was based on Total Mixed Ration (TMR) doses. Dry cows received about $15 \mathrm{~kg}$ of TMR dose and straw ad libitum, while lactating cows $50.3 \mathrm{~kg}$ TMR daily. The diets were balanced with regard to the energy content, crude protein and minerals. The dietary nutrient content for dairy cows is given in Table 1. The composition of TMR dose applied in the study stayed intact. Experimental design, blood sampling and analysis

The study was conducted on 38 multiparous cows in the period 3-14 days prepartum, and selected with respect to the condition, i.e. cows of $B C S>4$ pts. (group I, n=18) and cows of $B C S<4$ pts. (group II, $\mathrm{n}=20$ ). The method of assessment was consistent with the recommendations of the European Association of Fleckvieh Cattle Breeders ( $1=$ thin cow, 5=over conditioned cow). The assessment was done by the same person 3-14 days prepartum (start of the experiment), 1-2 days prepartum, 1-2 days postpartum, and in the 3rd week of lactation. The animals were clinically healthy, and aged 4-8 years.

The blood for analysis was collected from an external vein into disposable test tubes without anticoagulant addition in the morning before feed application between 3rd and 14th days prepartum (38 cows), and then on the days when the condition was assessed: 1-2 days prepartum, 1-2 days postpartum and in the 3rd week of lactation.

Laboratory analyses were conducted with the Pentra 400 biochemical analyser (Horiba ABX Diagnosis, Montpellier Cedex, France). The following factors were analysed in the blood serum:

- $\beta$-hydroxybutyrate acid (BHBA), nonesterified fatty acids (NEFA) by the enzymatic method with the use of Randox reagents, Ireland (Randox Laboratories, Antrim, UK);

- glucose by the oxidase method with the use of HORIBA ABX reagents;

- triacylglycerols (TAG), total cholesterol by enzymatic methods, HORIBA ABX reagents;

- asparginian aminotransferase (AST), alanine aminotransferase (ALT), alkaline phosphatase (ALP) and $\gamma$-glutamylotransferase (GGT) enzymes activity by the kinetic method, HORIBA $A B X$ reagents;

- total bilirubin concentration by the colorimetric method, HORIBA ABX reagents;

- total protein and albumin and urea by the colorimetric method, HORIBA ABX reagents.

Cows were milked twice daily in a double-12 parallel milking parlour and milk yield was recorded from which a weekly average for each cow was calculated for weeks 1-4 postpartum. Representative milk samples were analysed for protein, fat, lactose using a Bentley 150 Infrared Milk Analyzer (Bentley Instruments, Chaska, USA). Sample milking was conducted in the 3rd week of lactation (end of collected the blood). Body mass was determined before calving and at the 3rd week of lactation.

\section{Statistical analysis}

The results of the study were subject to statistical analysis using the SAS statistical packet (SAS 2009) based on a linear model from GLM procedure that respected:

$$
x_{i j}=\mu+s_{i}+e_{i j}
$$

where $x_{i j}$ is the the observed values of an analysed parameter, $\mu$ is the mean of the parameter in a population, $s_{i}$ is the the effect of $i$-th -year of cows' birth and $e_{i j}$ is the an error. 
Significance of differences between mean values in both groups was determined using Duncan's test.

\section{Results}

According to the methodology it was assumed the condition of cows from group I was higher before the parturition (4.23 pts.) when compared to group II (3.76 pts.). The condition of cows tended to decrease up to the 3rd week of lactation (Figure 1). Before calving the body mass of cows with a high BCS score was significantly $(P<0.01)$ higher. A significant $(P<0.01)$ decrease in body mass from the 3rd week of lactation when compared to the beginning of the study was observed in both groups (Table 2).

The decrease in condition in group I $(P<0.01)$ was higher when compared to group II $(P<0.05)$. No significant differences between the groups in terms of the yield and composition of milk were observed (Table 2).

Table 2

Milk yield, milk composition and body weight $(\overline{\mathrm{X}} \pm \mathrm{s})$

\begin{tabular}{lcc}
\hline Item & Group I & Group II \\
\hline Milk parameters & & \\
Milk, kg & $37.40 \pm 10.75$ & $36.21 \pm 5.11$ \\
Fat, $\%$ & $3.90 \pm 0.39$ & $3.85 \pm 0.83$ \\
Protein, $\%$ & $3.62 \pm 0.25$ & $3.58 \pm 0.30$ \\
Lactose, $\%$ & $4.87 \pm 0.07$ & $4.85 \pm 0.20$ \\
Body weight, kg & & \\
Prepartum & $* * 780 \pm 36 \mathrm{~A}$ & $* * 714 \pm 31 \mathrm{~B}$ \\
3 weeks postpartum & $* * 640 \pm 39$ & $* * 647 \pm 38$ \\
\hline
\end{tabular}

** significance of differences between the groups within collection with $P \leq 0.01,{ }^{A}, B$ Significant differences are marked with different letters between the groups $P \leq 0.01$

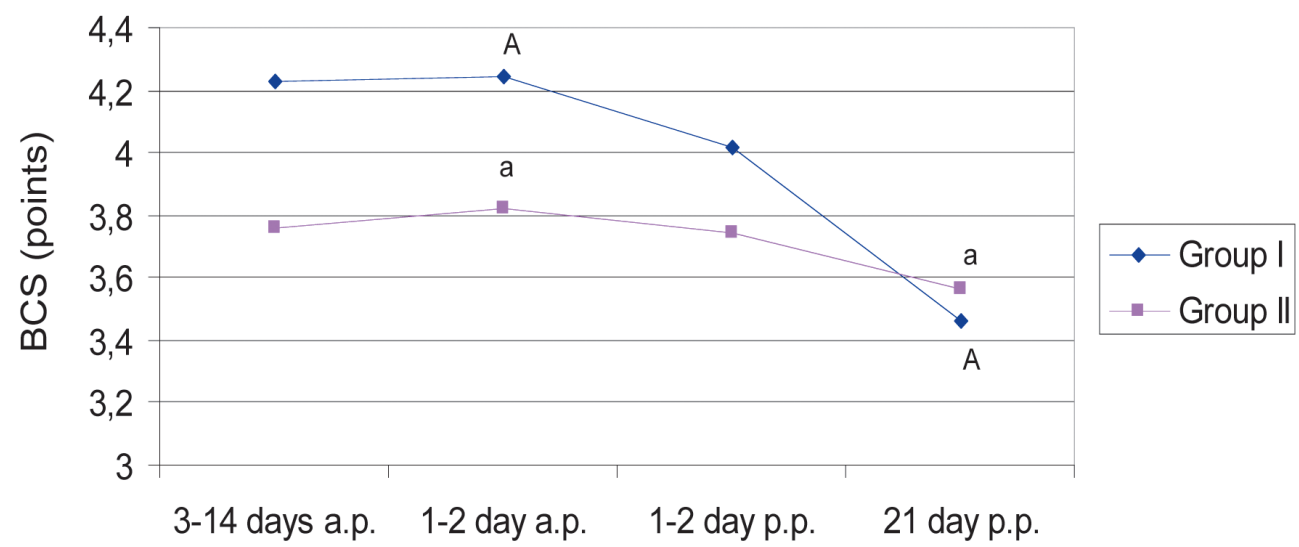

a/A: significance of differences between particular days of assessment with $P \leq 0.05 / P \leq 0.01$

Figure 1

Estimation of cow condition by BCS method (points) 
Mean values for selected serum lipid-carbohydrate parameters are presented in Table 3. A slight increase in glucose concentration in blood serum in group I (high condition) was noted directly after parturition (1-2 days postpartum). This could have resulted from physiological postpartum stress and higher secretion of glicocorticoids that increase the glucose level. In the 3 rd week of lactation the level of glucose was subject to a significant $(P<0.01)$ decrease in group I when compared to other studied periods. Differences between the groups were significant $(P<0.01)$. Before the parturition (1-2 days) the concentration of BHBA in blood in group II was lower $(P<0.05)$ when compared to group I. Up to the 3rd week of lactation a statistically significant increase in BHBA was noted in group II. An increase $(P<0.05)$ in NEFA concentration in the prepartum period was observed in group II. A slight increase $(P<0.05)$ in NEFA level was noted postpartum in cows from group I, characterised by an overnormative condition prepartum (Table 3). In the case of group II, the concentration of NEFA was subject to small changes up to the 3rd week of lactation. The level of triacylglycerols decreased significantly $(P<0.01)$ in the 3rd week of lactation in group I. In days $1-2$ and in the 3 rd week postpartum, the concentration of TAG in blood serum in group I was significantly $(P<0.01)$ lower when compared to group II. In the group of cows with an overnormative condition prepartum (group I) a decrease $(P<0.05)$ in cholesterol concentration in blood serum was observed directly postpartum (1-2 day) (Table 3). In the 3rd week of lactation, an increase in cholesterol level was distinct $(P<0.01)$ in both groups.

Table 3

Means for serum blood metabolite concentrations prepartum and postpartum ( $\overline{\mathrm{X}} \pm \mathrm{s})$

\begin{tabular}{|c|c|c|c|c|c|}
\hline Groups & $\begin{array}{l}\text { Glucose, } \\
\mathrm{mmol} / \mathrm{l}\end{array}$ & $\begin{array}{l}\text { BHBA, } \\
\mathrm{mmol} / \mathrm{I}\end{array}$ & $\begin{array}{l}\text { NEFA, } \\
\mathrm{mmol} / \mathrm{l}\end{array}$ & $\begin{array}{c}\text { TAG, } \\
\mathrm{mmol} / \mathrm{l}\end{array}$ & $\begin{array}{c}\text { Cholesterol, } \\
\mathrm{mmol} / \mathrm{l}\end{array}$ \\
\hline \multicolumn{6}{|c|}{ 3-14 day prepartum } \\
\hline I & $3.61^{A} \pm 0.56$ & $0.47 \pm 0.15$ & $0.41 \pm 0.28$ & ${ }^{*} 0.36^{A} \pm 0.06$ & $2.79^{\mathrm{Aa}} \pm 0.57$ \\
\hline II & $3.84 \pm 0.45$ & $0.43 \pm 0.11$ & $0.28^{\mathrm{b}} \pm 0.11$ & ${ }^{*} 0.32 \pm 0.07$ & $2.73^{\mathrm{D}} \pm 0.54$ \\
\hline \multicolumn{6}{|c|}{ 1-2 day prepartum } \\
\hline I & $3.84^{\mathrm{B}} \pm 0.65$ & ${ }^{*} 0.45 \pm 0.08$ & $0.37 \pm 0.16$ & $0.38^{\mathrm{B}} \pm 0.07$ & $2.59^{B} \pm 0.36$ \\
\hline II & $3.72 \pm 0.54$ & ${ }^{*} 0.34^{\mathrm{A}} \pm 0.10$ & $0.47^{b} \pm 0.31$ & $0.30 \pm 0.10$ & $2.48^{\mathrm{E}} \pm 0.38$ \\
\hline \multicolumn{6}{|c|}{ 1-2 day postpartum } \\
\hline I & $3.96^{C} \pm 1.08$ & $0.38 \pm 0.13$ & $0.33^{\mathrm{a}} \pm 0.14$ & ${ }^{* *} 0.21^{C} \pm 0.06$ & $2.40^{\mathrm{Ca}} \pm 0.47$ \\
\hline II & $3.73 \pm 0.84$ & $0.38 \pm 0.24$ & $0.38 \pm 0.24$ & ${ }^{* *} 0.29 \pm 0.10$ & $2.56^{\mathrm{F}} \pm 0.50$ \\
\hline \multicolumn{6}{|c|}{3 weeks postpartum } \\
\hline I & $* * 2.45^{A B C} \pm 0.45$ & $0.53 \pm 0.40$ & $0.51^{\mathrm{a}} \pm 0.26$ & ${ }^{* *} 0.10^{\mathrm{ABC}} \pm 0.03$ & $3.59^{A B C} \pm 0.48$ \\
\hline II & $* * 3.39 \pm 0.76$ & $0.50^{A} \pm 0.23$ & $0.41 \pm 0.24$ & ${ }^{* *} 0.26 \pm 0.12$ & $3.39^{\mathrm{DEF}} \pm 0.73$ \\
\hline
\end{tabular}

*significance of differences between groups within sampling with $P \leq 0.05,{ }^{* *}$ significance of differences between groups within sampling with $P \leq 0.01$, ${ }^{a}, \mathrm{~b}$ Significance of differences marked with different letters between particular days of assessment in a group with $P \leq 0.05, \quad A, B, C, D, E, F$ Significance of differences marked with different letters between particular days of assessment in a group with $P \leq 0.01$

No significant differences in AST and ALT activity between the groups before the parturition were observed (Table 4). An increase in AST activity up to $79.13 \mathrm{U} / \mathrm{I}$ was noted at 1-2 days postpartum in group I. A lower increase was observed in cows from group II, and differences between the groups were significant $(P<0.05)$. In the 3rd week of lactation, an increase in ALT activity $(P<0.01)$ was observed in both groups. On the day of the beginning of the study higher $(P<0.05)$ activity of GT was noted in cows from group I, however the activity of that 
enzyme postpartum was subject to decrease $(P<0.05)$. Similarly, in the period 3-14 days prepartum, higher $(P<0.01)$ activity of ALP was noted in group I, and it decreased postpartum $(P<0.01)$. A higher concentration of total bilirubin $(5.11 \mu \mathrm{mol} / \mathrm{I})$ was observed prepartum in group I $(P<0.01)$. A similar relationship was noted in the case of GGT and ALP activity. A significant increase in bilirubin concentration $(P<0.01)$ was observed postpartum $(1-2$ days $)$ in group II $(5.18 \mu \mathrm{mol} / \mathrm{l})$. This value was subject to decrease in subsequent sampling $(P<0.01)$ to the level of $3.32 \mu \mathrm{mol} / \mathrm{l}$.

Table 4

Enzyme activity and total bilirubin content in blood serum ( $\bar{X} \pm s)$

\begin{tabular}{|c|c|c|c|c|c|}
\hline Groups & $\begin{array}{l}\text { AST, } \\
\mathrm{U} / \mathrm{I}\end{array}$ & $\begin{array}{l}\text { ALT, } \\
\mathrm{U} / \mathrm{I}\end{array}$ & $\begin{array}{l}\mathrm{GGT}, \\
\mathrm{U} / \mathrm{I}\end{array}$ & $\begin{array}{l}\text { ALP, } \\
\mathrm{U} / \mathrm{I}\end{array}$ & $\begin{array}{c}\text { Total bilirubin, } \\
\mu \mathrm{mol} / \mathrm{l}\end{array}$ \\
\hline \multicolumn{6}{|c|}{ 3-14 day prepartum } \\
\hline I & $63.28^{\mathrm{Aa}} \pm 11.71$ & $20.01^{\mathrm{a}} \pm 2.44$ & $* 23.46^{\mathrm{a}} \pm 6.37$ & $* * 111.45^{\mathrm{ABa}} \pm 53.08$ & $* * 5.11 \pm 1.53$ \\
\hline ॥ & $60.12 \pm 12.50$ & $19.80^{c} \pm 4.44$ & ${ }^{*} 19.72 \pm 4.24$ & ${ }^{* *} 61.46 \pm 37.31$ & $* * 2.80^{\mathrm{aA}} \pm 0.99$ \\
\hline \multicolumn{6}{|c|}{ 1-2 day prepartum } \\
\hline I & $61.64^{\mathrm{Bb}} \pm 6.49$ & $18.91^{A} \pm 3.33$ & $21.04 \pm 5.33$ & $82.12^{\mathrm{a}} \pm 27.96$ & $4.51 \pm 2.19$ \\
\hline ॥ & $59.13 \pm 10.81$ & $16.86^{\mathrm{BC}} \pm 3.36$ & $19.54 \pm 4.73$ & $72.55 \pm 32.33$ & $4.03^{\mathrm{a}} \pm 1.78$ \\
\hline \multicolumn{6}{|c|}{ 1-2 day postpartum } \\
\hline I & ${ }^{*} 79.13^{\mathrm{AB}} \pm 16.51$ & ${ }^{*} 20.21^{\mathrm{b}} \pm 2.13$ & $19.34^{\mathrm{a}} \pm 4.41$ & ${ }^{*} 61.15^{A} \pm 24.56$ & $4.33 \pm 1.71$ \\
\hline ॥ & *66.42 \pm 16.58 & ${ }^{*} 17.81^{\mathrm{e}} \pm 4.52$ & $21.04 \pm 5.91$ & ${ }^{*} 82.80 \pm 29.36$ & $5.18^{\mathrm{AB}} \pm 1.13$ \\
\hline \multicolumn{6}{|c|}{3 weeks postpartum } \\
\hline । & $75.53^{\mathrm{ab}} \pm 23.59$ & $22.67^{\mathrm{Aab}} \pm 4.91$ & $21.04 \pm 6.89$ & $61.55^{\mathrm{B}} \pm 27.20$ & $3.88 \pm 2.56$ \\
\hline ॥ & $68.04 \pm 11.52$ & $20.96^{\mathrm{Be}} \pm 3.47$ & $20.24 \pm 4.41$ & $58.32 \pm 55.51$ & $3.32^{B} \pm 1.67$ \\
\hline
\end{tabular}

${ }^{*}$ significance of differences between groups within sampling with $P \leq 0.05, \quad{ }^{* *}$ significance of differences between groups within sampling with $P \leq 0.01$, a,bSignificance of differences marked with different letters between particular days of assessment in a group with $P \leq 0.05, A, B, C, D, E, F$ Significance of differences marked with different letters between particular days of assessment in a group with $P \leq 0.01$

Table 5

Content of total protein, albumins and urea in blood serum $(\bar{X} \pm s)$

\begin{tabular}{lccr}
\hline Group & Total protein, $\mathrm{g} / \mathrm{l}$ & Albumin, $\mathrm{g} / \mathrm{l}$ & Urea, $\mathrm{mmol} / \mathrm{l}$ \\
\hline 3-14 day prepartum & & & \\
I & $65.68 \pm 4.76$ & $* * 32.63^{\mathrm{A}} \pm 1.15$ & $5.60^{\mathrm{A}} \pm 1.50$ \\
II & $61.80^{\mathrm{b}} \pm 10.54$ & $* * 30.46 \pm 2.64$ & $5.37 \pm 1.61$ \\
1-2 day prepartum & $* * 66.71 \pm 5.56$ & ${ }^{*} 32.03^{\mathrm{B}} \pm 0.95$ & $5.14 \pm 0.93$ \\
I & $* * 59.85^{\mathrm{aA}} \pm 7.07$ & $*^{*} 30.46 \pm 2.22$ & $4.96 \pm 0.81$ \\
II & & & \\
1-2 day postpartum & $64.76 \pm 10.15$ & $31.51^{\mathrm{a}} \pm 3.22$ & $4.58^{\mathrm{AB}} \pm 1.05$ \\
I & $66.72^{\mathrm{a}} \pm 9.13$ & $31.34 \pm 2.82$ & $4.70^{\mathrm{a}} \pm 1.21$ \\
II & & & \\
3 weeks postpartum & $68.51 \pm 8.01$ & $29.90^{\mathrm{ABa}} \pm 1.73$ & $5.73^{\mathrm{B}} \pm 0.97$ \\
I & $68.31^{\mathrm{Ab}} \pm 4.23$ & $30.89 \pm 2.41$ & $5.73^{\mathrm{a}} \pm 1.26$ \\
\hline II & & &
\end{tabular}

*significance of differences between groups within sampling with $P \leq 0.05 ;{ }^{* *}$ significance of differences between groups within sampling with $P \leq 0.01$; a,bSignificance of differences marked with different letters between particular days of assessment in a group with $P \leq 0.05$. $A, B, B, C, D, E, F$ Significance of differences marked with different letters between particular days of assessment in a group with $P \leq 0.01$ 
Higher $(P<0.01)$ concentration of total protein was observed in blood serum of cows from group I in the period 1-2 days prepartum, when compared to group II (Table 5). Up to the 3rd week of lactation, the content of TP in blood of cows from group II increased $(P<0.01)$. A higher content of albumins (similar to the situation with TP) was noted prepartum in group I, and it tended to decrease successively $(P<0.01)$ up to the 3 rd week of lactation. When compared to the beginning of the study, the content of urea in group I was subject to decrease to 1-2 days postpartum, and then it increased $(P<0.01)$. The content of urea in blood serum in group II in $3 r d$ week of lactation reached the same value as in the case of group I $(5.73 \mathrm{mmol} / \mathrm{l})$.

\section{Discussion}

The body condition score of cows at calving and its decrease in the period of early lactation were connected with a risk of metabolic diseases (Heuer et al. 1999), deterioration in fertility and milk yield (Heuer et al. 1999, Reksen et al. 2002). The decrease in the condition of HolsteinFriesian cows (Hachenberg et al. 2007) and Czech Fleckvieh (Jílek et al. 2008) reflects the degree of energy deficiency, since mobilization of body fat is associated with the negative energy balance postpartum.

It was not proved in the case of Czech Fleckvieh cows that a higher BCS value prepartum was connected with a higher decrease of BCS postpartum, without any influence on reproduction (Jilek et al. 2008). In the present study, the decrease in the BCS condition of cows with a high score prepartum was significant $(P<0.01)$ up to the 3 rd week. It was, however, the short period postpartum. Roche et al. (2007) stated that the BCS at the lowest point was positively correlated with $\mathrm{BCS}$ at calving. The degree of BCS condition decrease as observed in the present study in both groups was also observed in the case of a large population of Czech Fleckvieh cows (Jílek et al. 2008). Cows of the Simmental breed with the condition $<3.5$ pts. in the 1st week postpartum are characterized by the highest milk yield in the first 5 months of lactation (Jílek et al. 2008). In the present study, cows with an overnormative condition prepartum were characterized by a slightly higher condition in that period, that could have been connected to the changes in milk yield in the case of longer study.

The decrease in glucose level in the first weeks postpartum is a demonstration of metabolic adaptation to the start of lactation (Studziński et al. 2003, Dann et al. 2005). The occurrence of a negative energy balance may be connected with a decrease in the glucose content in blood to a level even over $1 / 3$, and with an increased level of ketone compounds and FFA (Studziński et al. 2003). In the present study cows in which BCS condition was high prepartum, a significant lower $(P<0.01)$ concentration of glucose in blood was observed in the $3 \mathrm{rd}$ week of lactation when compared to cows with a lower condition prepartum, i.e. 2.45 vs. $3.39 \mathrm{mmol} / \mathrm{l}$, however, with a lack of intensified lipolysis and ketogenesis. The concentration of BHBA in blood serum during the whole research period was considerably below the boundary value of $1.4 \mathrm{mmol} / \mathrm{l}$ in both groups (Carrier et al. 2003, Oetzel 2004, Kupczyński et al. 2005). Any risk of subclinical ketosis was noted during the research period. The observed value of BHBA before parturition (108 days) was at the level of 218$884 \mu \mathrm{mol} / \mathrm{l}$ (Quiroz-Rocha et al. 2009). The values observed in the present study were from 0.28 to $0.47 \mathrm{mmol} / \mathrm{l}$ on average, and were higher with higher condition. In the case of highyielding cows of the Holstein-Friesian breed in turn, there is a risk of an excessive lipolysis 
in the first weeks of lactation, even proper feeding and the application of glucogenic precursors (Kupczyński et al. 2005).

The proper level of NFA in blood serum in dairy cows from 14 to 2 days prepartum should be lower than $0.4 \mathrm{mmol} / \mathrm{l}$ (Oetzel 2004). In the present study on Czech Fleckvieh cows the content of NEFA in that period was $0.41 \mathrm{mmol} / \mathrm{I}$ (group I) and $0.28 \mathrm{mmol} / \mathrm{I}$ (group II). In spite of this fact, no excessive lipolysis was noted postpartum. In the study with crossbreds of beef breeds, it was observed that cows with a high condition at calving were characterised by lower NEFA concentration in blood (Vizcarra et al. 1998). The differences were not significant in the present study. The decrease in fodder intake observed in the perinatal period (Ferlay et al. 2006) causes an intensified lipolysis of the reserve fat (Studer et al. 1998). The manifestation of these changes is an increase in NEFA level in blood directly before calving, reaching a peak 3-5 days postpartum. The return to their low concentration takes place about 14-21 days postpartum (Vazquez-Añon et al. 1994). In high yielding cows of PHF breed, an intensified lipolysis may be maintained up to the 3rd week of lactation (Kupczyński et al. 2005). The yield of analysed Czech Fleckviech cows in that period was $37.4 \mathrm{~kg}$ of milk (group I), and $36.2 \mathrm{~kg}$ (group II), however, no overnormative increase of NEFA in blood serum was not observed. Cows of the Montbéliarde breed grazed on pasture for 6 weeks were characterised by an increased concentration of NEFA and BHBA that points to insufficient nutrition (Ferlay et al. 2006). Breed differences were also demonstrated in another study (French et al. 2006). In the period 3 days prepartum to 1 day postpartum, the level of FFA for Holstein and Jersey breeds was 775 vs. $521 \mu \mathrm{Eq} / \mathrm{L}$, respectively (French et al. 2006). Body condition score at parturition and postpartum nutrition influence the occurrence of luteal activity and the concentration of glucose, insulin, and nonesterified fatty acids in the plasma of primiparous beef cows (Vizcarra et al. 1998). The highest concentration of FFA in blood of Holstein-Friesian cows was noted in the 1st week of lactation (Hachenberg et al. 2007) pointing to the fact that the concentration of FFA $>0.5 \mathrm{~mol} / \mathrm{l}$ in that period is a significant criterion limiting the possibilities of metabolic adaptation post calving. Beef cows with a BCS lower at parturition had a decrease in circulating NEFA and an increase in serum GH (Lake et al. 2006). Even postpartum dietary lipid supplementation does not appear to influence metabolic signals associated with nutrient partitioning in beef cows during early lactation. TAG concentration in blood tends to decrease with hyperketonemia severity (Marczuk \& Filar 2003). In the present study, TAG content in the 3rd week of lactation in cows that had a high prepartum condition decreased to a lower limit of reference values (Meyer \& Harvey 1998). An increase in BHBA was not observed. A higher level of triglycerides and similar of total cholesterol when compared to the present study was observed in the case of dairy type Simmental cows (Borucka-Jastrzębska et al. 2007). The reduction of serum cholesterol is related to the switch in synthesis of lipoproteins from the hepatocytes (Quiroz-Rocha et al. 2009). An increase in cholesterol levels after parturition, irrespective of the condition of cows, was observed in the present study.

Parturition and starting lactation influence the activity of AST in blood serum of cows of a condition higher before the parturition (group I). Marczuk \& Filar (2003) point out the special usefulness of the determination of GLDH, GGT, AST activity and bilirubin concentration for the recognition of subclinical impairments and liver disorders like fatty liver. The changes 
observed in the present study were not intensified, which proves the proper functioning of the liver. The observed activities of enzymes in the blood in both groups did not diverge from values observed in cows of the Holstein-Friesian breed (Mordak \& Nicpoń 2006).

The concentration of total bilirubin during the whole research period did not exceed the reference values (Meyer and Harvey 1998). A higher concentration of bilirubin prepartum was noted in cows with higher BCS; however that did not influence its content postpartum. The value of that index in cows with subclinical ketosis was at the level of $7.27 \mu \mathrm{mol} / \mathrm{l}$ (Nowakowski 2008), and in cows with subclinical form of fatty liver in 1-2 weeks postpartum it was $14.2 \mu \mathrm{mol} / \mathrm{l}$ (Marczuk \& Filar 2003). The results of the present study demonstrate a lower risk of hyperbilirubinemia incidence in Simmental cows when compared to HolsteinFriesian ones.

The concentration of total protein and albumins in blood serum in the perinatal period was within the reference values (Meyer \& Harvey 1998). The fluctuations observed in the perinatal period were small; however, they were confirmed statistically. Levels of urea similar to that observed in the present study were found in cows of the Montbeliard breed grazed on pasture (Ferlay et al. 2006). In the present study, a decrease in urea level $(P<0.01) 1-2$ days postpartum was observed in cows with a higher condition prepartum. Quiroz-Rocha et al. (2009) suggest that reduced dry matter intake might cause a drop in ammonia absorption, causing a shift of urea being recycled in the rumen, which may explain the lower serum concentrations of urea in the postpartum period.

It should be stated in summary that changes in Czech Fleckvieh breed cows in the transition period do not clearly influence milk yield and composition. An excessive BCS condition before calving leads to its higher decrease at the beginning of lactation what may indirectly point to higher energy deficiency. It is confirmed by a decrease $(P<0.01)$ in glucose concentration in blood serum in the $3 \mathrm{rd}$ week of lactation when compared to cows with a proper condition before calving ( 3.39 vs. $2.45 \mathrm{mmol} / \mathrm{l}$ ). Overnormative condition of cows before calving also negatively influences the content of TAG, ALP and Total bilirubin concentration in blood serum on the first days after calving. In cows with high condition before calving, the transport of TAG from liver to blood is impaired at the beginning of lactation. The present study demonstrates that in the Czech Fleckvieh breed of dairy type, intensified lipolysis and ketogenesis in the perinatal period (1-2 prepartum to 1-2 days postpartum) do not take place, pointing to high adaptation possibilities of the metabolism. Directed biochemical analysis of blood in the perinatal period allows metabolic disorders in subclinical form to be detected, thus avoiding the risk of the development of full-blown disease symptoms.

\section{References}

Borucka-Jastrzębska E, Kańczuga D, Orowicz W (2007) Blood lipid profile of Simmental breed cattle depending on the age. Med Weter 63, 836-838 [in Polish]

Bremmer DR, Trower SL, Bertics SJ, Besong SA, Bernabucci U, Grummer RR (2000) Etiology of fatty liver in dairy cattle: effects of nutritional and hormonal status on hepatic microsomal triglyceride transfer protein. J Dairy Sci 83, 2239-2251

Carrier J, Stewart S, Godden S, Fetrow J, Rapnicki P (2003) Evaluation and use of three cowside tests for detection of subclinical ketosis in early postpartum cows. J Dairy Sci 87, 3725-3735 
Dann HM, Morin DE, Bollero GA, Murphy MR, Dracley JK (2005) Prepartum intake, postpartum induction of ketosis, and periparturient disorders affect the metabolic status of dairy cows. J Dairy Sci 88, 3249-3264

Ferlay A, Martin B, Pradel P, Coulon JB, Chilliard Y (2006) Influence of grass-based diets on milk fatty acid composition and milk lipolytic system in Tarentaise and Montbéliarde cow breeds. J Dairy Sci 89, 40264041

French PD (2006) Dry matter intake and blood parameters of nonlactating Holstein and Jersey cows in late gestation. J Dairy Sci 89, 1057-1061

Hachenberg S, Weinkauf C, Hiss S, Sauerwein H (2007) Evaluation of classification modes potentially suitable to identify metabolic stress in healthy dairy cows during the peripartal period. J Anim Sci 85, 1923-1932

Heuer C, Schukken YH, Dobbelaar P (1999) Postpartum body condition score and results from the first test day milk as predictors of disease, fertility, yield, and culling in commercial dairy herds. J Dairy Sci 82, 295-304

Jílek F, Pytloun P, Kubešova M, Štípková M, Bouška J, Volek J, Frelich J, Rajmon R (2008) Relationships among body condition score, milk yield and reproduction in Czech Fleckvieh cows. Czech J Anim Sci 53, 357-367

Kupczyński R, Janeczek W, Pogoda-Sewerniak K (2005) The study on an application of different doses of propylene glycol in cows in perinatal period. Med Weter 61, 194-199 [in Polish]

Lake SL, Scholjegerdes EJ, Hallford DM, Moss GE, Rule DC, Hess BW (2006) Effects of body condition score at parturition and postpartum supplemental fat on metabolite and hormone concentrations of beef cows and their suckling calves. J Anim Sci 84, 1038-1047

LeBlanc SJ, Leslie KE, Duffield TF (2005) Metabolic predictors of displaced abomasum in dairy cattle. J Dairy Sci $88,159-170$

Marczuk J, Filar J (2003) An assessment of liver impairment and its functional disorders in the course of an excessive fat mobilization in dairy cows. Med Weter 2003, 59, 47- 50 [in Polish]

Meyer DJ, Harvey JW (1998) Veterinary laboratory medicine. Interpretation and diagnosis. 2nd ed. WB Saunders Company, USA

Mordak R, Nicpoń J (2006) Haematological and metabolic parameters of blood in cows in perinatal period and an increasing lactation. Med Weter 62, 1292-1294 [in Polish]

Nowakowski $\mathrm{H}$ (2008) The results of chosen biochemical parameters $\mathrm{i}$ the aspect of functional state of liver in the course of primary ketosis in cows. Med Weter 64, 197-201 [in Polish]

Oetzel GR (2004) Monitoring and testing dairy herds for metabolic disease. Vet Clin North Am Food Anim Pract $20,651-674$

Quiroz-Rocha GF, LeBlanc SJ, Duffield TF, Wood D, Leslie KE, Jacobs RM (2009) Reference limits for biochemical and hematological analytes of dairy cows one week before and one week after parturition. Can Vet J 50, 383-388

Rajala-Schultz PJ, Gröhn YT, McCulloch CE (1999) Effects of milk fever, ketosis, and lameness on milk yield in dairy cows. J Dairy Sci 82, 288-294

Reksen O, Havrevoll Ø, Gröhn YT, Bolstad T, Waldmann A, Ropstad E (2002) Relationships among body condition score, milk constituents, and postpartum luteal function in Norwegian dairy cows. J Dairy Sci $85,1406-1415$

Roche JR, Macdonald KA, Burke CR, Lee JM, Berry DP (2007) Associations among body condition score, body weight, and reproductive performance in seasonal-calving dairy cattle. J Dairy Sci 90, 376-391

Rodenburg J (1992) Body condition scoring of dairy cattle. Ontario Ministry of Agriculture and Food Fact Sheet, $411 / 10$

SAS (2009) User's Guide v9.0. SAS Institute Inc., Cary, NC, USA

Studer E (1998) A veterinary perspective of on-farm evaluation of nutrition and reproduction. J Dairy Sci 81, 872-876

Studziński T, Filar J, Czarnecki A, Madej E (2003) Hormonal and metabolic predispositions of an adaptation in perinatal period and early lactation in cows. Med Weter 59, 811-816 [in Polish] 
Vazquez-Añon M, Bertics S, Luck M, Grummer RR, Pinheiro J (1994) Peripartum liver triglyceride and plasma metabolites in dairy cows. J Dairy Sci 77, 1521-1528

Vizcarra JA, Wettemann RP, Spitzer JC, Morrison DG (1998) Body condition at parturition and postpartum weight gain influence luteal activity and concentrations of glucose, insulin, and nonesterified fatty acids in plasma of primiparous beef cows. J Anim Sci 76, 927-936

Received 3 March 2010, accepted 13 April 2011.

Corresponding author:

Robert Kupczyńki

email: robert.kupczynski@up.wroc.pl

Department of Animal Hygiene and Environment Wrocław University of Environmental and Life Sciences Chełmońskiego 38 C, 51-630 Wrocław, Poland 